\title{
Recasting the Threat of Chemical Terrorism in the EU: the Issue of Returnees from the Syrian Conflict
}

\author{
Caitríona MCLEISH*
}

\begin{abstract}
Chemical terrorist attacks by non-state actors have traditionally been characterised as low probability events; however, the apparent normalisation of chemical weapons use, including by terrorists, in the ongoing conflict in Syria is causing some in the international security community to question whether it will remain low probability. For Europe there is an additional potential concern, namely the numbers of EU citizens who are "foreign fighters" and whose return from the conflict zone might also result in "importing" chemical weapons use. This article examines the rise of the "chemical weapons-returning foreign fighter" narrative and considers aspects of the European response. These responses predate the current concerns and include important efforts to create a robust public health response, such as early alert and communication systems, so that the attractiveness of these weapons being used within a European context might be reduced. Although there are limitations as to how far one can transfer what happens in a Syrian context to Europe, the suggestion is made that some of the framing assumptions within this response architecture may be now inadvertently limiting the potential to identify and respond to chemical attacks.
\end{abstract}

\section{INTRODUCTION}

At the beginning of March 2017, the International Committee of the Red Cross regional director for the Middle East, Robert Mardini, issued the following statement:

"During the past two days, [West Erbil Emergency] hospital has admitted five children and two women showing clinical symptoms consistent with an exposure to a blistering chemical agent. The use of chemical weapons is absolutely prohibited under international humanitarian law. We are deeply alarmed by what our colleagues have seen, and we strongly condemn any use of chemical weapons, by any party, anywhere."1

\footnotetext{
* The author would like to thank James Revill and Julian Perry Robinson from the Harvard Sussex Program and Hylke Dijkstra and Anniek de Ruijter for their comments on, and discussions around, early drafts of this paper. Thanks also go to Gunnar Jeremias and Jez Littlewood for engaging in early conceptual discussions about this issue. The author would also like to thank the anonymous reviewers for their helpful comments and suggestions. This work was supported by two Economic and Social Research Council grants: ES/L014505/1 on Data Capture of Syria Chemical Weapons Allegations; and ES/K011324/1 on Strategic Governance of Science and Technology Pathways to Security. Data citation is included in the references and the body text of the paper.

1 International Committee of the Red Cross, "Iraq: ICRC strongly condemns use of chemical weapons around Mosul" (3 March 2017), available at <www.icrc.org/en/document/iraq-icrc-strongly-condemns-use-chemicalweapons-around-mosul> accessed 10 March 2017.
} 
This recent allegation of chemical weapons use in the ongoing conflict in Syria and Iraq joins countless others that have been made since 2012. All sides stand accused, regime forces as well as non-regime, including the terrorist group Da'esh (also known as ISIS, ISIL, Islamic State). For a weapon that had been considered de-legitimised as a currency of power, the allegations of repeated use, a number of which have been confirmed through United Nations investigation, have shocked. Indeed such is their number that some observers caution that chemical weapons use may be becoming normalised. $^{2}$

Alongside many countries, representatives from European states have strongly condemned these uses of chemical weapons. However it is the idea of non-state actors using chemical weapons that appears to particularly exercise them. France, for example, recently noted that "The danger of the use of chemical weapons is real. Non-State actors no longer hesitate to use them"3 and Germany has gone further, suggesting that it should be "no surprise to us that a barbaric group of merciless people such as the so-called ISIL does not recognise any limits regarding the weaponry it uses." 4 Slovakia, on behalf of the EU, has also spoken of how "gravely concerned" the EU is "about the risk of State and non-State actors acquiring such weapons, which has already become a dark reality in the Syrian Arab Republic and Iraq." In expressing these sentiments, Europe does not stand alone. For example, Julie Bishop, Australia's Foreign Minister, described what is happening in Syria and Iraq as meaning that "long accepted paradigms" and "conventional wisdom" regarding the "terrorist intention to acquire and weaponise chemical agents has been largely aspirational" are "becoming obsolete". 6

Non-state actor use of chemical weapons has a particular salience to European states because of another striking feature of the conflict, namely the number of European nationals that have travelled to the region to join groups such as Da'esh. The outward flow of these citizens to the conflict zone poses obvious external security issues to Europe, but their return may also pose problems for internal security and public health. With Da'esh now found through UN investigation to have used chemical weapons, a new variation on this internal security narrative has emerged, namely that returning foreign fighters may somehow "import" chemical weapons use to Europe. ${ }^{7}$

This article explores how this new chemical weapons variation of the returning foreign fighter narrative has emerged. In doing so the article details how activities to reduce European vulnerabilities to chemical terrorist attack predate the current security concerns about Syria and have evolved within a particular cognitive framing and conceptualisation of what is and is not chemical terrorism. Whilst there are very real limitations as to how far

\footnotetext{
2 See, for example, R Guthrie, as quoted in E Graham-Harrison, "Chemical weapons attacks in Syria may normalise war crimes, experts warn" The Guardian (11 August 2016).

3 France "Statement by H.E. Ambassador Mr Philppe Lalliot Permanent Representative of France" Eighty-Second Session of the Executive Council (OPCW, 2016).

4 Germany "Statement by HE Ambassador Christoph Israng Permanent Representative of the Federal Republic of Germany" Eighty-third Session of the Executive Council (OPCW, 2016).

5 Slovakia "Statement on behalf of the European Union delivered by H.E. Ambassador Roman Buzek permanent representative of Slovakia to the OPCW" Eighty-third Session of the Executive Council (OPCW, 2016).

6 Minister for Foreign Affairs, Australia, “Address to Australia Group Plenary”(5 June 2015), available at <http:// foreignminister.gov.au/speeches/Pages/2015/jb_sp_150605.aspx>.

7 Europol, TE-SAT 2016, European Union Terrorism Situation and Trend Report 2016, 2016. doi:10.2813/525171.
} 
one can - and should - apply the sort of "terrorist activity transfer" narrative which is now apparent, in this article I suggest that a cognitive bias in how we understand what constitutes a chemical terrorist attack may be inadvertently limiting our ability to prepare and respond to a chemical terrorist attack. In order to further reduce vulnerabilities to chemical attacks, a re-examination of conceptualisations may be needed.

The article begins by detailing chemical weapons use in Syria and Iraq, placing a particular emphasis on use by Da'esh and possible initial acquisition routes. The article then proceeds to discuss how what is happening in Syria and Iraq links to what is being portrayed as "the biggest security issue" currently facing Europe, namely the return of the large numbers of Europeans who have participated in the conflict. ${ }^{8}$ The article then turns to the multifaceted policy responses and notes their evolution from being framed largely as an external issue to increasingly both an internal and external issue. This evolution becomes more apparent in the discussion that follows, which details the evolution of the chemical terrorism threat narrative. The article concludes with a reflective discussion about how the framing assumptions imbued within our responses may inadvertently limit our ability to respond and suggests the need for thinking again about what chemical terrorism means in a European context.

\section{Shifting Normative LANDSCAPES: Chemical WeAPons USE IN Syria AND IRAQ}

The first allegations that chemical weapons (CW) were being used in Syria began to emerge in 2012 and increased throughout 2013 until they reached a climax in late August with the use of the nerve agent sarin in the Ghouta suburbs of Damascus. ${ }^{9}$ Since then, and despite Syria becoming a state party to the Chemical Weapons Convention (CWC) and having its (declared) CW stockpiles removed, allegations that toxic chemicals are being used as weapons of war have continued, seemingly unabated. ${ }^{10}$

Because the allegations continued after Syria had joined the CWC in September 2013, the Director General of the international implementing organisation of that convention, the Organisation for the Prohibition of Chemical Weapons (OPCW), decided to establish a FactFinding Mission (FFM) to "establish facts surrounding" allegations of use. ${ }^{11}$ That decision was driven in part because confirmation that toxic chemicals were being used as weapons would constitute a gross violation of the fundamental purpose of the Convention - to exclude completely, for the sake of all mankind, the possibility of the use of chemical weapons. ${ }^{12}$

The FFMs did go on to establish that toxic chemicals had been used in some of the allegations they investigated but their mandate did not extend to attribution. In other words

\footnotetext{
8 M Banks, "Returning foreign fighters are biggest threat to EU, Parliament warned" The Parliament Magazine (12 October 2016).

9 For attacks prior to Ghouta see, for example, J Perry Robinson, “Alleged use of chemical weapons in Syria” 2013, 4, Harvard Sussex Program Occasional Paper, 13 June, available at <www.sussex.ac.uk/Units/spru/hsp/occasional\% 20papers/HSPOP_4.pdf> accessed 25 September 2017.

10 See, for example, A MacDonald and A Ullah, "Three years after Ghouta, chemical weapons used 'over and over again' in Syria” Middle East Eye (22 August 2016).

11 Organisation for the Prohibition of Chemical Weapons, "OPCW to Undertake Fact-Finding Mission in Syria on Alleged Chlorine Gas Attacks" (The Hague, 29 April 2014), available at <www.opcw.org/news/article/opcw-toundertake-fact-finding-mission-in-syria-on-alleged-chlorine-gas-attacks/> accessed 27 September 2017.

12 Convention on the Prohibition of the Development, Production, Stockpiling and Use of Chemical Weapons and on Their Destruction (adopted 13 January 1993, entered into force 29 April 1997) Preamble.
} 
the FFMs established use, but not by whom. That was/is the mandate of the Joint UN-OPCW Investigation Mechanism (JIM) ${ }^{13}$ and in the course of their first year of work the JIM found "sufficient evidence" to attribute agency in four out of nine cases they investigated. In three of the cases, all involving chlorine barrel bombs, they determined that the Syrian Air Force was responsible; in the fourth case they determined that Da'esh had used sulphur-mustard filled artillery shells. ${ }^{14}$ In all cases, the health impacts were rapid and localised.

Two characteristics of these cases are worth noting. The first is that they involved the use of "crude" chemicals - chlorine and mustard agents - conveyed, in three cases, by equally basic delivery systems, ie barrel bombs. Crude here is a reference to the agents not being the so-called classical CW agents but instead toxic industrial chemicals. The idea that these types of toxic chemicals rather than the more sophisticated CW agents might find utility in contemporary conflicts has been warned about for some time, with experts positing that factors other than relative aggressivity, for example accessibility, availability and/or terrorising potentiality, may now drive decisions about whether or not to use CW. ${ }^{15}$

The second aspect worth noting is that all sides in the conflict stand accused and have been found wanting. Whilst it was the regime accusing their opponents of using toxic chemicals that triggered the very first set of investigations in the summer of 2013, accusations pertaining to use by Da'esh began appearing in the open domain more frequently in late 2014/early 2015. ${ }^{16}$ Reports over those months appeared also to suggest an evolution in their capabilities first in delivery systems (from vehicle-borne improvised explosive devices to mortar attacks ${ }^{17}$ ) then in agents used (from chlorine to mustard agents ${ }^{18}$ ).

How Da'esh first acquired its CW capability and the nature of its current CW capability is not reported with certainty within open literature, though at least three potential pathways are suggested. The first two suggest that acquisition was based on availability. One pathway stresses Iraq's former CW programme and in particular the looting of the Saddam Hussein era site at Muthanna. According to reports of a letter written by the Iraqi UN ambassador, Mohamed Ali Alhakim, to the UN General Secretary in July 2014 "the project manager (of Muthanna) spotted the looting of some equipment via the camera surveillance system before the 'terrorists' disabled it". ${ }^{19}$ The same reports suggest that bunkers 13 and 41 were amongst those buildings looted. ${ }^{20}$ Both of these bunkers are known chemical munition storage bunkers, with the former

13 United Nations Security Council (7 August 2015) Resolution 2235.

14 The incidents investigated and attributed to the Syrian air force were at Talmenes in the Idlib governorate on 21 April 2014; and at Qmenas and Sarmin both in the Idlib governorate 16 March 2015. The attack attributed to Da'esh was at Marea, Aleppo governorate on 21 August 2015. See OPCW/UN, "Third Report of the Organization for the Prohibition of Chemical Weapons-United Nations Joint Investigative Mechanism” (2016).

15 See, for example, G Pearson, "The importance of implementation of the General Purpose Criterion of the Chemical Weapons Convention" (2006) 55 Chemistry in Industry 413, 414 and J Perry Robinson, "Difficulties facing the Chemical Weapons Convention" (2008) 84 International Affairs 226-227.

16 See Associated Press Iraq, "Islamic State used chemical weapons against peshmerga, Kurds say" The Guardian (London, 14 March 2015).

17 G Winfield, "Bitter as the cud" CBRNe World (18 October 2016), available at <www.cbrneworld.com/news/ bitter_as_the_cud\#axzz4b3nxZIZ2> accessed 27 September 2017.

18 See A Entous, "Islamic State Suspected of Using Chemical Weapon, US Says" Wall Street Journal (13 August 2015).

19 E Lederer, "Iraq: 'Terrorists' seize ex-chemical weapons site" Associated Press (9 July 2014), available at <http:// bigstory.ap.org/article/iraq-says-terrorists-seize-chemical-weapons-site>.

20 ibid. 
declared by the Iraqi's as containing about 2,500 rockets filled with sarin before the structure was damaged by aerial bombardment in $1991 .^{21}$ Whilst this acquisition pathway may appear sound, experts query it, including Zanders who contends that any sarin that might have been found by Da'esh at al Muthanna was "highly likely [to] have degraded below any useful degree of purity." 22

The second "availability" pathway suggests the Syrian regime as the source of Da'esh capabilities. A recent Foreign Policy article detailing what it calls "the story of Abu Ahmad, a Syrian operative for the Islamic State" dates acquisition to December 2012 when anti-regime groups, including Da'esh, overran a regime army base known as Regiment 111 and took possession of "barrels filled with chlorine, sarin and mustard gas." 23 The suggestion that the regime may be the source of Da' esh's chemical weapons was also stated in one of the rare occasions that a Da'esh fighter publically justified their use of chemical weapons. $^{24}$

Both of these pathways suggest that Da'esh had/has no indigenous $\mathrm{CW}$ production capability but rather that availability figured/figures highly in their decision-making process. By contrast, the third pathway suggests Da'esh sought/seeks its own crude production capability by deliberately recruiting former CW scientists and "highly technically trained professionals, including from the West". ${ }^{25}$ In the category of former weapons scientists associated with Da'esh was Abu Malik, who was described as working "at Saddam Hussein's Muthana chemical weapon production facility before affiliating with al Qaeda Iraq in 2005 and later joining Da'esh." ${ }^{26}$ His death in 2015 was expected to "temporarily degrade and disrupt....and diminish" Da'esh's ability to produce chemical weapons. ${ }^{27}$ So too was the capture of "Abu Dawud, ISIL's emir of chemical and traditional weapons manufacturing" in March 2016 - he was said to have provided information about their $\mathrm{CW}$ production facilities and those involved in the effort. ${ }^{28}$ Six months after his capture US forces announced that they had struck what they called a pharmaceutical plant complex that been had converted into a $\mathrm{CW}$ production site. $^{29}$

\footnotetext{
21 United Nations Monitoring, Verification and Inspection Commission (UNMOVIC), Compendium of Iraq's Proscribed Weapons Programmes in the Chemical, Biological and Missile Areas (June 2007), Chapter III: Chemical Weapons Programme, 292.

22 JP Zanders, "What's he building in there?" (2014) August CBRNe World 8, 10.

23 H Doornbos and J Moussa, "How the Islamic State Seized a Chemical Weapons Stockpile" Foreign Policy (17 August 2016), available at <http://foreignpolicy.com/2016/08/17/how-the-islamic-state-seized-a-chemicalweapons-stockpile/>.

24 H Johnson, "On Chemical Weapons and Red M\&M's, an Islamic State Fighter Defends the Cause" Foreign Policy (1 September 2015), available at <http://foreignpolicy.com/2015/09/01/on-chemical-weapons-and-red-mms-anislamic-state-fighter-defends-the-cause/>.

25 Minister for Foreign Affairs, Australia, supra, note 6.

26 US Central Command, "ISIL Chemical Weapons Expert Killed in Coalition Airstrike" (31 January 2015), available at <www.centcom.mil/MEDIA/NEWS-ARTICLES/News-Article-View/Article/884941/isil-chemical-weaponsexpert-killed-in-coalition-airstrike/>.

27 ibid.

28 US Department of Defense, "Press Briefing by Pentagon Press Secretary Peter Cook" (10 March 2016), available at

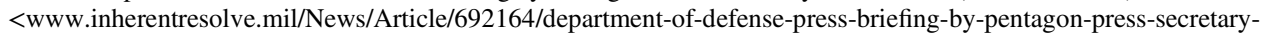
peter-cook/>.

29 L Dearden, "ISIS chemical weapons manufacturing facility that posed 'significant threat' destroyed by air strikes in Iraq" The Independent (London, 14 September 2016).
} 


\section{The “BigGeSt SECURITY ISSUE" FACING EUROPE}

It is the idea that Da'esh might be deliberately recruiting "highly trained professionals, including from the West" that turns chemical weapons use taking place in Syria and Iraq into a potential internal problem for Europe. Foreign fighter ${ }^{30}$ mobilisation is neither new in conflicts nor for the current proponents of "jihadi terrorism." ${ }^{31}$ However, it is the sheer numbers that have departed Europe for the region since 2013, recently estimated as exceeding 5,800, that means the issue has both "internal" and "external" security dimensions for Europe. ${ }^{32}$ This dual "internal/external" framing of the issue has been present in documents and speeches since the beginning of the conflict. A report published by the EU's Counter Terrorism Co-ordinator in January 2011, for example, notes that "a significant number of radicalised people travel from the EU to conflict areas or are attending terrorist training camps and then returning to Europe. They pose a clear threat to internal security." 33 Over the course of six years the perception that this threat has grown is such that returning foreign fighters are now considered the "biggest security issue" currently facing Europe. ${ }^{34}$

As primary actors in security matters, governments across much of Europe have responded by enacting a range of measures in an effort to stem the outward flow of citizens. Travel to the conflict zone has been criminalised; new legislation related to countering extremism has been introduced; prosecutorial powers have been enhanced, as have the powers of the security services. In addition, counter radicalisation and counter narrative programmes have been established. ${ }^{35}$ At the European level, a spectrum of activities have been important in supporting EU Member States, not least because of the similarity in the nature of the challenges and the scale of the phenomenon. At one end of this spectrum are initiatives such as the Radicalisation Awareness Network that links practitioners from around Europe who work daily with people who have already been radicalised or who are vulnerable to radicalisation. In addition, the network

\footnotetext{
30 Despite the phrase having currency in the media and policy-making circles, there is no agreed (legal or academic) definition of "foreign fighter." Within the academic literature a range of definitions are found. Some are broad based definitions, such as Cerwyn Moore and Paul Tumelty's definition as "non-indigenous, non-territorialized combatants who, motivated by religion, kinship, and/or ideology rather than pecuniary reward, enter a conflict zone to participate in hostilities" and Ian Bryan's description of them as being "not agents of foreign governments, but they leave home typically to fight for a transnational cause or identity." Others are more restrictive, such as Thomas Hegghammer's definition that a "foreign fighter [is] an agent who (1) has joined, and operates within the confines of, an insurgency, (2) lacks citizenship of the conflict state or kinship links to its warring factions, (3) lacks affiliation to an official military organization, and (4) is unpaid." See C Moore and P Tumelty, "Foreign Fighters and the Case of Chechnya: A Critical Assessment" (2008) 31 Studies in Conflict and Terrorism 412; I Bryon, "Sovereignty and the Foreign Fighter Problem" (2010) 54 Orbis 115; T Hegghammer, "The Rise of Muslim Foreign Fighters: Islam and the Globalization of Jihad" (2010-11) 45 International Security 54.

31 For more see Hegghammer, supra, note 30, 53-54; M Flores, "Foreign fighter involvement in national and international wars" in A de Guttry, F Capone and C Paulussen (eds), Foreign Fighters under International Law and Beyond (The Hague, Asser Press, 2016); J Rehman, Islamic State Practices, International Law and the Threat from Terrorism (Oxford, Hart Publishing, 2005).

32 Center for the Analysis of Terrorism, "European Jihadi Watch" 3 March 2017, available at <http://cat-int.org/ wp-content/uploads/2017/03/European-jihad-watch-20170306_eng-1.pdf>.

33 EU Counter Terrorism Coordinator, "EU Action Plan on combatting terrorism" 15893/1/10 REV 1 (17 January 2011).

34 Banks, supra, note 8.

35 For an overview of Member States' actions in this area see <https://ec.europa.eu/home-affairs/what-we-do/ networks/radicalisation_awareness_network/ran-and-member-states/repository $>$.
} 
provides a platform for peer support and sharing of best practices and the associated Centre of Excellence also supports the Commission and Member States in their work. ${ }^{36}$ At the other end of the spectrum, efforts have concentrated on, amongst other things, the strengthening the external borders including by negotiating a revision to the Schengen Borders Code. ${ }^{37}$

The spectrum approach at both the European and Member State level appears to have been successful in slowing the rate of those travelling from Europe to the conflict zone. One European state, for example, reported to the UN Sanctions and Monitoring Team in January 2017 that "while some [of its citizens] were still attempting to travel to the conflict zone, the flow was much reduced, down from up to 100 individuals per month in 2013 and 2014 to fewer than 5 per month in 2016."38

Increasingly however, the focus of policy concern has turned to address those that may return. In part this is linked to recent territorial losses experienced by Da'esh and the expected fall of Raqqa. Some European officials believe this will lead to large numbers of citizens returning to Europe, including larger numbers of those who will return with the express intention of bringing the conflict to Europe. ${ }^{39}$

Whilst it is acknowledged that "returning" is done for a variety of reasons, including disillusionment, it is those who might return to Europe still committed to Da'esh and the conflict that particularly worries officials. ${ }^{40}$ Statistical analysis suggests that only a small percentage who return will fall into this category, however there is a concern that this may change as higher numbers return to Europe. ${ }^{41}$ The "authority" to attack Europe has been given by leaders such as Abu Mohammad al-Adnani, the former Da'esh spokesperson, who advocated amongst other things the use of poison on "the disbelieving American, Frenchmen or any of their allies" and Al Qaeda's leader Ayman al-Zawahiri. ${ }^{42}$ Worryingly, the work of Thomas Hegghammer suggests that if terrorist attacks involve returnees then they are more likely to be successful and result in higher casualties. ${ }^{43}$ Proponents of this view point to the involvement of returnees in incidents such as the Brussels Jewish Museum attack in May 2014; the January 2015 attacks on the headquarters of the satirical newspaper Charlie Hebdo, and the subsequent

36 See <https://ec.europa.eu/home-affairs/what-we-do/networks/radicalisation_awareness_network_en>.

37 European Council Press, "Schengen borders code: Council adopts regulation to reinforce checks at external borders" (7 March 2017), available at <www.consilium.europa.eu/en/press/press-releases/2017/03/07-regulationreinforce-checks-external-borders/ $>$.

38 UN 2017, p 7.

39 P Wintour, "Islamic State fighters returning to UK 'pose huge challenge", The Guardian (London, 9 March 2017 ).

40 A connected concern regards foreign fighters using social media to inspire attacks in their former home countries. The French Da'esh member Rachid Kassim, for example, is said to be behind several plots in France and has been vocal on social media calling for attacks in European countries and attacks on individuals such as religious leaders and politicians. See A Amarasingam, "An Interview with Rachid Kassim, Jihadist Orchestrating Attacks in France” 2016 Jihadology (November).

41 T Hegghammer and P Nesser, "Assessing Islamic State's Commitment to Attacking the West" (2015) 9 Perspectives on Terrorism 14, 20.

42 AM Al Adnani, In the Name of Allah the Beneficent the Merciful Indeed Your Lord Is Ever Watchful (9 September 2014), available at <https://quotecatalog.com/communicator/abu-muhammad-al-adnani/> and Reuters "Al Qaeda chief urges lone wolf attacks, militant unity" (13 September 2015), available at <www.reuters.com/article/us-mideastzawahri-idUSKCNORD0E920150913>.

43 T Hegghammer, "Should I Stay or Should I Go? Explaining Variation in Western Jihadists' Choice between Domestic and Foreign Fighting" (2013) 107 American Political Science Review 1, 10. 
attack on a kosher supermarket in Paris; the November 2015 Paris attacks and the Brussels airport and metro attacks in March 2016. However, conducting attacks using guns and improvised explosive devices in Europe is not the same as conducting attacks with toxic chemicals.

\section{The EVOlVING THREAT TO EUROPEAN SECURITY}

Current policy responses to the perceived foreign fighter threat to European internal security can be traced to the 2005 European Union Strategy for Combating Radicalisation and Recruitment to Terrorism, ${ }^{44}$ which itself was a reaction to the 2004 Madrid and 2005 London bombings. This strategy was typical of the relatively general, and indeed externally facing, approach that was taken to address the issue of foreign fighters before the European Council charged that "the creation of an Islamic Caliphate in Iraq and Syria and the Islamist-extremist export of terrorism on which it is based, is a direct threat to the security of the European countries." 45

As the issue took on a more internal security dimension, additional effort has ensued to encourage the accelerated implementation of a package of measures to support Member States in such ways as enhancing the ability to share information, deepening cooperation between security services and enhancing the criminal justice response. Institutional expansion has also occurred, including through the establishment of the European Counter Terrorism Centre in January 2016, which is described as:
"a platform through which Member States can increase information sharing and operational cooperation with regard to: the monitoring and investigation of foreign terrorist fighters; the trafficking of illegal firearms; and terrorist financing and the identification of additional lines of investigations." 46

This description implies a work focus on "conventional" forms of terrorism rather than those involving toxic chemicals. This is understandable, given the rarity of deliberate chemical incidents compared to the unfortunately more frequent conventional attacks. However, in a recent report, the Counter Terrorism Co-ordinator noted that not all Member States are taking advantage of the institutional arrangement and opportunity to share information. Indeed, he described the levels of information sharing as not sufficient and not reflecting the threat. ${ }^{47}$

In much the same way that the foreign fighter issue was portrayed as largely an external security issue before the caliphate was declared, the EU and Member States tended to frame CW use in Syria and Iraq as an external threat until Da'esh began to be directly accused of using them. Until this, much of the European action was focused on reducing the external threat. In their 2013 Towards a Comprehensive Approach document, for example, the Council framed chemical and biological threats as follows:

\footnotetext{
44 European Council (24 November 2005), "European Union Strategy for Combating Radicalisation and Recruitment to Terrorism" 14781/1/05.

45 European Council, Special Meeting of the European Council, 30 August 2014, p 6.

46 See EU Counter-Terrorism Coordinator (4 March 2016), "State of play on implementation of the statement of the Members of the European Council of 12 February 2015, the JHA Council Conclusions of 20 November 2015, and the Conclusions of the European Council of 18 December 2015" 6785/16.

47 ibid.
} 


\begin{abstract}
"There are mounting concerns over reports of the use of chemical and biological weapons in Syria. The EU will continue calling for UN inspectors to be allowed into the country to investigate all such allegations. In order to prevent, detect and respond to such devastating events with potentially deadly consequences for the population in the region, the EU is currently examining possible options for further coordination and cooperation that could be explored with EU Member States, relevant international bodies (OCHA, ICRC, WHO, INTERPOL and OPCW) and strategic partners....

The EU will continue to urge Syria to accede to the Chemical Weapons Convention and to ratify the Biological Weapons Convention as a matter of urgency. The EU recalls that any use of chemical weapons by anyone under any circumstances would be reprehensible and completely contrary to the legal norms and standards of the international community. The Syrian authorities bear a particular responsibility to ensure that their chemical weapons are stored securely pending independently verified destruction and are not permitted to fall into the hands of any other State or non-state actor."48
\end{abstract}

The EU and Member States engaged vigorously in such efforts, including taking leading roles in the international effort to remove and destroy the declared stockpiles of chemical weapons from Syria.

By May 2014 the framing appears to have evolved to take on more internal considerations, as shown by the explicit mentions that Da'esh may seek to use chemical weapons in Europe appearing in documents such as Commission Communication to the European Parliament, Council, Economic and Social Committee and the Committee of the Regions. ${ }^{49}$ This communication noted that "even though terrorists have tended to use commercial or homemade explosives, CBRN agents such as sarin, ricin or anthrax also represent a serious threat". ${ }^{50}$ No elaboration is given, which is as one might expect in a public document of this type, but interestingly the connection to the issue of returning foreign fighters is made immediately:

"Latest reports suggest that of particular concern are returnees from Syria. Some of these and other radicalised individuals, having access to and working in sensitive areas might use their insider knowledge to strike against critical infrastructures, such as a water purification plant, or they may disable railways electrical power supplies. Such insider threats may have transnational impacts and therefore also pose threats to EU security." (emphasis added) ${ }^{51}$

The reframing of the threat as an internal issue resulted in the Commission urging that "a robust, better designed, and proportionate strategy to anticipate and deter" future chemical (biological, radiological, nuclear and high explosive) risks at EU level was needed. This was to include new or strengthened actions to tackle illegal methods of production, handling, concealing and storing of agents. ${ }^{52}$ Whilst perhaps only close EU observers may have been alert to this shifting narrative, certain media outlets, especially in the UK, began reporting that Da'esh would attack Europe

\footnotetext{
48 European Commission, Joint Communication to the European Parliament, the Council, the European Economic and Social Committee and the Committee of The Regions Towards a Comprehensive EU Approach to the Syrian Crisis (24 June 2013).

49 European Commission, Communication from the Commission to the European Parliament, The Council, the European Economic and Social Committee and the Committee of the Regions on a new EU approach to the detection and mitigation of CBRN-E risks (5 May 2014).

50 ibid pp 2-3; CBRN stands for chemical, biological, radiological and nuclear.

51 ibid.

52 ibid 3 .
} 
using chemical weapons. ${ }^{53}$ This idea received more widespread attention following the warning given by the then French Prime Minister to his Parliament that that Da'esh may use chemical and biological weapons in Europe. ${ }^{54}$ This warning was made in the aftermath of the November 2015 Paris terrorist attacks and in the apparent knowledge that an attempt to contaminate water supplies around Paris had just been foiled. $^{55}$

The attacks in Paris provided fertile ground for more open consideration in policy documents that Da'esh might employ non-conventional tactics in Europe, including through using chemical weapons. A December 2015 European Parliamentary Briefing Note, for example, argued that because Da'esh had "vowed that future strikes will be more lethal and even more shocking" than Paris,

"The European Union and its Member States must prepare for the possibility of a chemical or biological attack on their territory by the self-styled 'Islamic State in Iraq and the Levant (known variously as IS, ISIS or ISIL, and by the Arabic acronym 'Da'esh')". 56

The authors recommended alert and that "European governments and EU institutions ... should consider publicly addressing the possibility of a terrorist attack using chemical, biological, radiological or even nuclear materials." 57

Supporting the report's framing and recommendations was the work of "several experts", quoted in the paper as having previously written that "there is a genuine risk of ISIL/Da'esh using chemical, biological, radiological or even nuclear materials in the context of future attacks on European targets" and that "an improvised explosive device containing chemical or radioactive materials" was a possible next weapon of choice for them. ${ }^{58}$ One of the experts quoted in the Briefing Note was Nomi Bar-Yaacov, who had previously written:

"What makes ISIS so dangerous is its radical ideology coupled with its continued success in recruiting hundreds of foreign fighters, including some with degrees in physics, chemistry, and computer science, and some who have previously worked in Saddam Hussein's weapons of mass destruction (WMD) programme."59

The implication here and in reports such as Europol's 2016 European Union Terrorism Situation and Trend Report, ${ }^{60}$ which says "The phenomenon of individuals travelling for terrorist purposes to conflict zones increases the risk that expertise in the use of chemical weapons can be transferred to the European Union by returning foreign terrorist fighters...", is that what is happening in the Syrian and latterly Iraqi context can be easily

\footnotetext{
53 See, for example, M Robinson, "Hundreds of British jihadis trained to launch 'highly likely' chlorine gas attack on train, tube or football match in UK warns top chemical warfare expert" The Daily Mail (London, 23 March 2015); D Haynes and F Hamilton, "Rising fears of chemical attack by UK Jihadists; Isis terrorists turn to bombs laced with chlorine; Rennie: Carmichael must stay" The Times (London, 25 May 2015).

54 A search of the European newspapers on the Nexis database using the search terms "chemical weapons" and "Valls" returns 72 hits in the two days after the Prime Minister, Monsieur Valls, made his statement.

55 Europol, supra, note 7, 14.

56 European Parliament Briefing, "ISIL/Da'esh and 'non-conventional' weapons of terror" (December 2015).

57 ibid.

58 ibid.

59 N Bar-Yaacov, "What if Isis launches a chemical attack in Europe?" The Guardian (London, 27 November 2015).

60 Europol, supra, note 7.
} 
imported to Europe. This is highly questionable for a number of reasons, including, as Burton noted:

"Just as fighting an insurgency is different from fighting a pitched battle or conventional war, it also different from conducting clandestine operations in a hostile environment, far from your base of support." 61

Burton goes on to say that whilst this does not make an attack using something that had proved successful in another context impossible, it does make it much more challenging, requiring additional obstacles to be overcome. When reflecting on chemical terrorism being imported to Europe the same reasoning also applies: whilst an attack is not impossible, simply put Europe is not Syria or Iraq. Ensuring that Europe is/remains an "inhospitable environment" to such forms of terrorism is therefore essential. ${ }^{62}$

\section{COUntering the "NEW" CHEMiCAL TERRORISM THREAT}

As stated above, the competence to respond to the now increasingly intertwined potential threat from foreign fighters and chemical terrorism lies with the Member States. However, because both issues have potential cross-border implications, there has been much European activity and again much of it predates the current security situation. Some of this activity falls under the general anti-terrorism umbrella or slightly more specific CBRN umbrella. Thus, for example, we can refer to chemical terrorism being included in EC definitions of terrorism since the 2002 Framework Decision on Combating Terrorism. As with this decision document, much of the current activity is in reaction to past terrorist events. As the European Commissioner for Security, Julian King, recently stated, the EU needs "to learn from each attack so that we are able to turn yesterday's terrorist successes into tomorrow's terrorist failures." ${ }^{63}$ Whilst this is true, what happens when past use is rare?

Within the European context, the idea that a chemical terrorism attack might occur has traditionally been characterised as a low probability event. As with other low probability threats, bespoke systems or policies tend not to be created and instead are added onto, or merged into, related efforts. Such is the case with responding to chemical terrorism, where a wide set of policies enacted for other reasons can be viewed as pertinent to reducing potential vulnerabilities that might be exploited by terrorists. These include policies and schemes related to the transport of dangerous goods, improvements to the physical security and safety of sites that contain large quantities of dangerous substances, setting storage threshold quantities at such facilities and the classification, packaging and labelling of chemical substances and mixtures.

Perhaps most central to creating and/or maintaining an inhospitable environment for chemical terrorism is possessing a robust public health response. This is recognised by the EU, and much effort has been spent developing a European health security framework. This framework is based around the three pillars of prevention, preparedness

61 F Burton, in M Kenney, Organization Learning and Islamic Militancy Project report number 226808 (US Department of Justice, 2009) 117.

62 See G Ackerman in MM Hafez and M Rasmussen, "Terrorist Innovations in Weapons of Mass Effect: Preconditions, Causes, and Predictive Indicators. Workshop Report" 2010.

63 J King, "Keynote address at Security and Defence Conference 2017" Chatham House, London, 6 March 2017. 
and response. Within the response pillar, the ability to circulate specialist information in a most timely fashion to relevant actors, including those in public health, is essential and various early alerting and communication systems for incidents that may/will have cross-border implications have been set up.

In the chemical area such are the potential routes of contamination that a number of these alert systems, none of which were created specifically for deliberate releases of chemicals, are relevant. These include the Rapid Alert System for Food and Feed (RASFF); the Industrial Accident Notification System (IAN); the Major Accident Reporting System (eMARS); and the early warning system associated with the European Monitoring Centre for Drugs and Drug Addiction (REITOX).

To reconcile the need for multiple event reporting, the 2013 European Parliament Decision on Serious Cross-Border Threats to Health decision linked these and all other reporting platforms with one overarching system, the Early Warning and Response System (EWRS). ${ }^{64}$ Incidents are input into the EWRS if the event satisfies the following conditions:

- it is unusual or unexpected for the given place and time, or it causes or may cause significant morbidity or mortality in humans, or it grows rapidly or may grow rapidly in scale, or it exceeds or may exceed national response capacity; and

- it affects or may affect more than one Member State; and

- it requires or may require co-ordinated response at the Union level.

However, not all chemical incidents, deliberate or otherwise, would satisfy this criteria. But if they should, the EWRS platform uses a free text data entry system so as to allow the person inputting to be comprehensive in passing on information relating to source: type of risk, number of cases and deaths, conditions affecting the spread, etc. ${ }^{65}$ This places an onus on communication skills.

By contrast, the more specialised alert system, RASCHEM, which sits below the EWRS, uses a "non free text" data entry system to record and exchange information about chemical incidents. Orford and colleagues consider this communication method to be preferable, as it allows information exchange more readily across the multiple European languages. Restricting free text, however, raises questions as to what assumptions are embedded within the standardised terms. ${ }^{66}$

Neither the EWRS nor RASCHEM systems are designed specifically for use in circumstances involving terrorism. This is the remit of a yet more focused alert system, RAS-BICHAT, which focuses only on the exchange of information on health threats due to deliberate release of chemical, biological and radio-nuclear agents by terrorists. This alert system became operational in 2002 and "hooks up with" EWRS, thus forming an important component of the European early alert and response

\footnotetext{
64 Commission Decision (2000/57/EC), "Commission Decision (2000/57/EC) of 22 December 1999 on the Early Warning and Response System for the Prevention and Control of Communicable Diseases under Decision No 2119/98/ EC of the European Parliament and of the Council" (OJ L 21, 26-1-2000, p 32).

65 R Orford et al, "EU alerting and reporting systems for potential chemical public health threats and hazards" (2014) 72 Environment International 15, 17.

66 ibid 19.
} 
architecture. $^{67}$ Notifications are made when a Member State suspects danger, when an incident might be of cross-border character and where a co-ordinated response might be needed, with the Commission acting as moderator, disseminating the notifications once they have been validated. For obvious reasons, the reaction to a notification being issued on this system is extremely rapid. Kjellén describes the process as follows:

"When a member state has posted an alert ... it generates a text message to all officers concerned at DG Health and Consumers. Member states must additionally phone the Commission's Security Office, which then contacts the officer on duty. To begin with, only that officer needs to act on the warning [presenting] him/herself at the office within one hour... Once onsite the on-duty officer examines the alert and verifies that it has been sent from an authorised source, whereupon a phone call is placed to the issuing member state to ensure that the message is correct and that no important information is missing ... After this procedure, the warning is disseminated through RAS BICHAT to all member states' points of contact and to the Health Security Committee which must be convened in the case of an emergency ... designated points of contact must visit the protected RAS BICHAT website to obtain full information on the incident. The member state must respond within an hour, and should a member state neglect to do this, the Commission will telephone the country in question for a follow-up ...."68

Should there be a serious crisis, the Commission's Health Emergency Operation Facility is used, which consists of both a crisis and communication centre. So as to ensure a high degree of coordination between different policies potentially affected in a CBRN incident with cross border potential (eg health and internal security, environment, agriculture, customs, civil protection), internal crisis coordination arrangements have been established. Known as ARGUS, the arrangement is designed to ensure rapid decision making and information sharing among all involved services and the various rapid alert systems mentioned above. ${ }^{69}$

\section{An OPPORTUNISTIC MOMENT FOR EVALUATION}

As can be seen, much effort has been expended prior to the current security situation towards reducing European vulnerabilities to chemical terrorism and ensuring that Europe is an inhospitable environment for this particular terrorist option. These efforts form part of the architecture that works to ensure that what appears possible for Da'esh to do in the Syrian and Iraqi environment is not directly nor easily transferable to the Europe context. Nevertheless such dedicated efforts do not mean that all vulnerabilities have been removed. For this reason, continuous effort is needed to reduce vulnerabilities and ensure responses are attuned to scenarios which are sensitive to the European context.

\footnotetext{
67 Netherlands, "Tasks and role of the European Commission in outbreak investigation, communicable disease surveillance and Health Security", Meeting of Experts to the Biological Weapons Convention, 21 July 2004.

68 SZ Kjellén, "Rapid alerts for crisis at the EU level" in Stefan Olson (ed), Crisis Management in the European Union: Cooperation in the Face of Emergencies (Springer Science \& Business Media, 2009) 67-68. At the time of writing it has not been possible to ascertain whether this system uses a free text or non free text data entry system.

69 For an overview, see Belgium "European Union capacities to respond to CBRN attacks and CBRN incidents", Meeting of Experts to the Biological Weapons Convention, 12 August 2010.
} 
Open source datasets record a small number of incidents involving toxic chemicals as having occurred in Europe between 2002 and 2014. ${ }^{70}$ As such, Europol's assessment that "CBRN materials and their precursors are under strict control of governments, keeping the threat at a minimal level" may be an appropriate assessment for traditionally conceived CW agents, but it does not sit as easily if the conceptualisation of a chemical attack is broadened. ${ }^{71}$ Indeed such an assessment may be seen as potential breeding ground for complacency.

Consideration of Da'esh's record in Syria and Iraq suggests availability as being an important criteria in their decision-making process. This criteria would seem like a good starting point for evaluation of the current mechanisms. As such, the recording in the same Europol report of two French chemical facilities being attacked in 2015 may need to be looked at again. ${ }^{72}$ There is past precedent for the deliberate targeting of chemical facilities so as to exploit the secondary effects of the toxic chemicals being released. ${ }^{73}$ Within the current Europol framing, these attacks are presumably not recognised as acts of chemical terrorism. In addition, details of that past precedent suggests they may not fulfil the cross-border criteria and so the above alert systems may not be activated.

From a legal and policy perspective this may seem a moot point to raise. If a chemical facility was attacked then appropriate action would be taken, but from a public health response perspective the ability to recognise a terrorist incident as being a chemical terrorist incident and circulating the right information to the right people in a timely fashion is essential. Health impacts following $\mathrm{CW}$ attacks are very likely to be rapid onset and so early and correct identification will be essential in reducing its potential health impact.

\section{Concluding Thoughts}

Primary responsibility for security issues such as terrorism lies with Member States, and so emphasis at the European level has been to facilitate the sharing of information and to establish robust crisis management tools that would support Member States should a crisis with cross-border implications occur. Within the public health response domain, early alerting and communication systems play an important role in lessening the potential impact of deliberate chemical attacks. As has been shown, several exist which are pertinent and alongside a spectrum of other policy measures form an impressive architecture that aims to make Europe an inhospitable environment for chemical weapon attacks.

Many of the policy responses that deal with the potential threat posed by returning foreign fighters and chemical terrorism were devised in reaction to past terrorist events. The 2004 and 2005 terrorist bombings in Madrid and London, as well as the more recent Paris attacks, appear to have been particularly important influencers in the current

\footnotetext{
70 As recorded in the Global Terrorism Database, <www.start.umd.edu/gtd/>. A note of methodological caution: amongst other things, these datasets will be incomplete both in terms of including only those instances which are in the open domain and in terms of reporting only those incidents which have either been successful or successfully foiled.

71 Europol, supra, note 7, pp 14 and 16.

72 ibid pp 13-14.

73 During the Bosnian conflict, for example, Serbian forces deliberately attacked chemical plants near Kutina, Jovan and Sisak over a two-year period so that environmental damage might be caused.
} 
anti-terrorism architecture. None of these were chemical terrorism incidents, but they can be linked to chemical weapons if the collective term CBRN-E is used. Indeed it has been noted above that early European Commission documents suggesting the potential internal security threat posed by chemical weapons and returning foreign fighters did, through reference to CBRN-E terrorist incidents. ${ }^{74}$

Despite being a frequently used collective term, CBRN-E is problematic for a number of reasons. This includes the way the term masks distinct technical and practical differences between the five weapons types. Indeed, by using the collective term yet referring mainly to E terrorist incidents - that is those involving explosives - an impression is given that the risk of chemical terrorism attacks and the risk from attacks using improvised explosive devices are equal. So too does linking uncritically the use of chemical weapons in Syria and Iraq with potential future use in Europe.

Coupling a rare event with one that is relatively more frequent can be "useful" in pushing the former towards the front burners of policymaking and stimulating policy action like, for example, ensuring that existing public health early warning systems also cover CW agents. However this same tactic can be misused. By hyping the rarer event and appearing to give it increased prevalence or reporting it as an inevitable certainty ${ }^{75}$ inappropriate and/or draconian knee-jerk policy responses may be fashioned. Equally as problematic is that it may also lead to "security theatre", where measures are put in place that give the perception of reducing vulnerabilities without actually doing so. ${ }^{76}$

In the case of the potential risk of returning foreign fighters importing chemical weapons use to Europe this has not yet happened. However, many of the public health early warning systems covering chemical warfare agents have been created for purposes other than terrorism. This suggests that there will be a number of embedded assumptions which have now been transposed to chemical terrorism response. If indeed this is the "biggest security issue" facing Europe, making these assumptions explicit and examining them, especially within the early alert systems, would seem a prudent action to take if potential vulnerabilities to chemical terrorism are to be reduced. The present security concerns regarding returning foreign fighters may therefore provide an opportune window to think again about chemical terrorism and whether, within a European context, our conceptualisation of what such a terrorist incident might look like is appropriate.

\footnotetext{
See European Commission, supra, note 49.

Supra, note 53.

76 See B Schneier, "Beyond security theater" (2009) 427 New Internationalist 10.
} 